Journal of Social Research in Uzbekistan

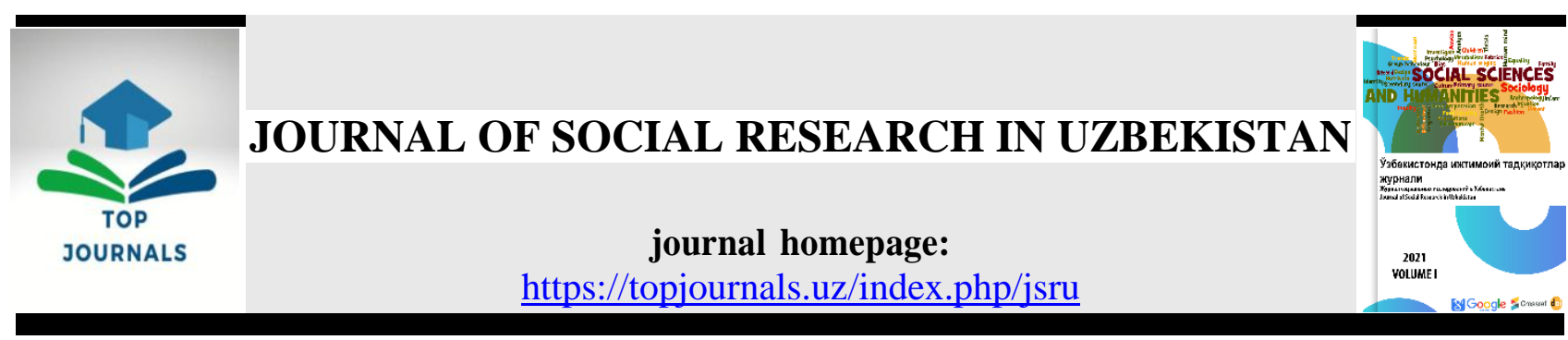

\title{
THEORETICAL AND CONCEPTUAL FUNDAMENTALS OF MANAGEMENT PERSONNEL COMPETENCE
}

\author{
Murat $\boldsymbol{U}$. Atamuratov \\ Associate Professor, PhD. \\ Tashkent State Technical University named after Islam Karimov \\ Uzbekistan \\ atamuratov78@rambler.ru
}

\section{ABOUT ARTICLE}

Key words: New Uzbekistan, Abstract: This article discusses the issues of management staff, management, competence, competence of managerial personnel, stages of public service, management potential, development and theoretical and conceptual theoretical and conceptual framework, foundations of improvement. The scientific views professional activity, coordination, training of foreign and domestic scientists on the concept programs. of "competence", the state policy of training management personnel and activities in accordance with modern trends in the world,

Received: 04.01.22

Accepted: 10.01 .22 linking professional knowledge, potential and growth of competencies are analyzed. The features Published: 29.01.22 of personnel policy in Uzbekistan and the activities of senior personnel in government bodies are also considered. In the context of the current global pandemic, proposals and recommendations are made to improve training programs for the formation of managerial competencies necessary in management. 


\title{
БОШҚАРУВ КАДРЛАР КОМПЕТЕНТЛИГИ МАСАЛАСИНИНГ НАЗАРИЙ-
} КОНЦЕПТУАЛ АСОСЛАРИ

\author{
Mypam У. Amaмypamoв \\ Доиент, $P$ hD. \\ Ислом Каримов номидаги Тошкент Давлат Техника Университети

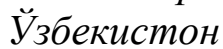 \\ atamuratov78@rambler.ru
}

МАҚОЛА ХАҚИДА

\begin{tabular}{|c|c|}
\hline $\begin{array}{l}\text { Калит сўзлар: Янги Ўзбекистон, } \\
\text { бошқарув кадрлари, бошқарув, компетен- } \\
\text { ция, давлат хизмати, бошқарув салохияти, } \\
\text { назарий-концептуал } \\
\text { профессионал } \\
\text { мувофиқлаштириш, ўқув дастурлар. }\end{array}$ & $\begin{array}{l}\text { Аннотация: } \\
\text { бошқарув казкур }\end{array}$ \\
\hline
\end{tabular}




\section{ТЕОРЕТИЧЕСКИЕ И КОНЦЕПТУАЛЬНЫЕ ОСНОВЫ КОМПЕТЕНЦИИ УПРАВЛЕНЧЕСКОГО ПЕРСОНАЛА}

\section{Мурат У. Атамуратов}

Доцент, кандидат технических наук (PhD)

Ташкентский государственный технический университет имени Ислама Каримова Узбекистан atamuratov78@rambler.ru

\section{O CTATbE}

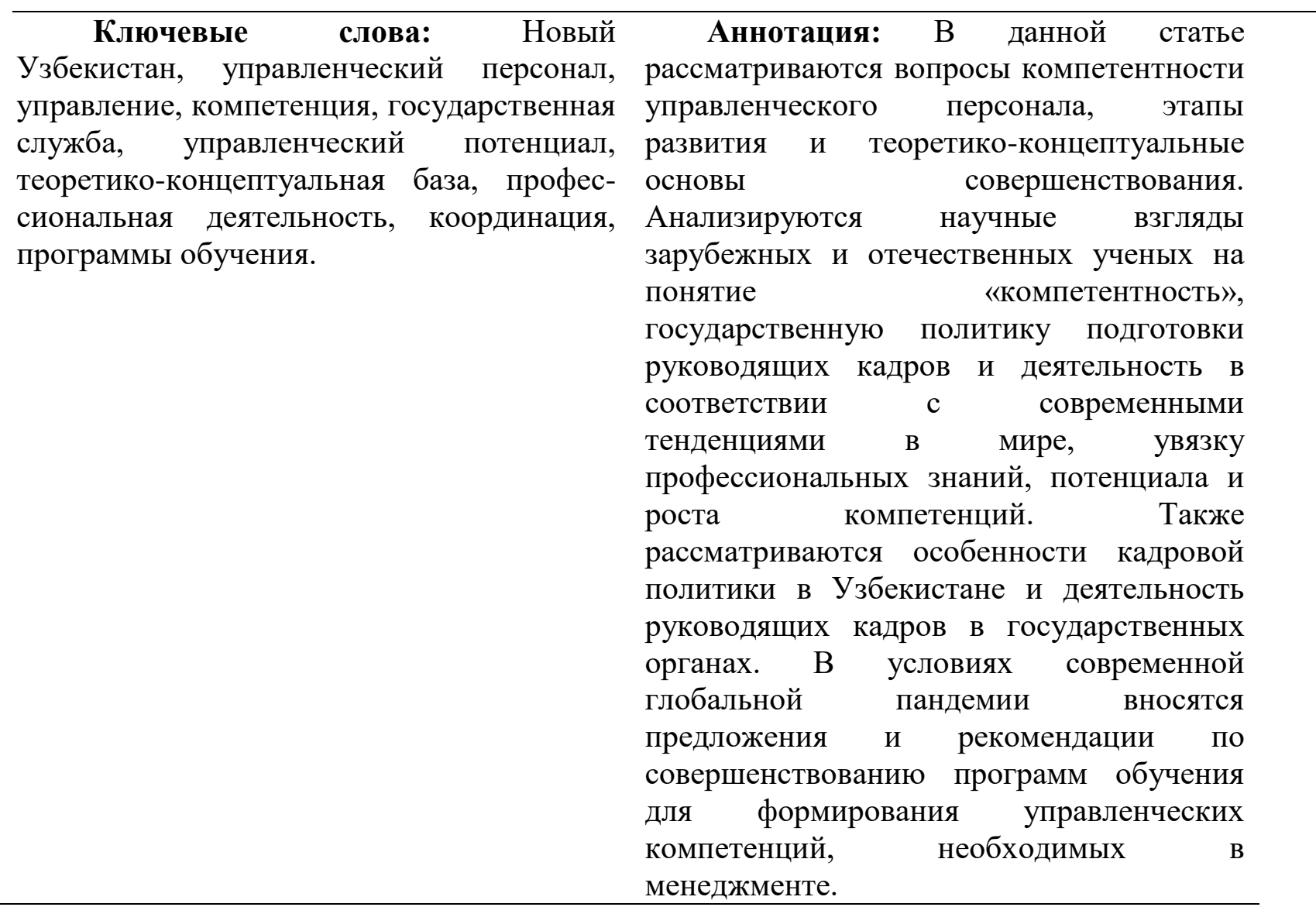




\section{Кириш /Введение /Intpoduction}

Янги Ўзбекистоннинг тарақиётини асоси бўлган ислохотларни амалга оширувчи рахбар кадрлар бошқарув компетенцияларини юксалтириш муносиб рахбар кадрлар тайёрлашнинг асоси хисобланади. Рахбар кадрларда бошқарув компетенцияларини ривожлантиришда икки мухим вазифа, яъни стратегик жихатдан инсон капиталини ривожлантириш, тактик жихатдан бозор иқтисодиёти талабларига мос билим ва малакаларни шакллантиришга эътибор қаратилади. Бу борада XX асрнинг 90-йилларида стратегик менежмент назариясида бошқарув компетенциялари доминант концепцияга айланиб, рахбар кадрларда бошқарув компетенцияларини ривожлантириш асосида рақобатбардош устунликларни шакллантиришни назарда тутиш мухим ахамият касб этган эди. Шу боисдан рахбар шахсининг асосий вазифаси одамларга хизмат қилиш, уларни рози қилишдан иборат бўлиб, улар ўз масъулияти ва жавобгарлигини, аввало, виждони олдида, унга ишонч билдирган одамлар, эл-юрт олдида чукур англаши, зиммасига юкланган вазифаларни адо этиш учун ўзи жонбозлик кўрсатиб, ўзгаларни хам фидокорликка чорлаши хамда ишлаши лозим. Шу боисдан бугунги кунда ушбу мақсадларга эришиш учун рахбарлар олдига мухим вазифалар кўйилиб, ушбу йўналишдаги тадқиқотларни янада кенгайтириш вазифалари турипти.

\section{Асосий қисм /Основная часть /Main part:}

Бугуни кунда бошқарув кадрлар компетентлиги ва унинг назарий асосларини ўрганиш, улар фаолияти юксалишининг назарий-концептуал асосларини такомиллаштиришда давлатнинг рахбар кадрлар тайёрлаш сиёсати ва дунёда кечаётган тенденциялар мухим рол уйнайди. Бу борада бугунги кунда бир қатор мухим вазифаларни амалга ошириш зарур бўлиб, улар куйидагилардан иборатдир:

-бошқарув кадрлар компетентлиги юксалишининг назарий-концептуал асосларига доир тадқиқотларни амалга ошириш;

-бошқарув кадрлар салохияти", "бошқарув кадрлари салохиятини ривожлантириш механизми" тушунчалари мазмунининг ўзига хос хусусиятларини аниқлаш.

- кадрлар технологияларини ишлаб чиқишнинг бошланғич шарти сифатида бошқарув кадрлар салохиятини бахолаш мезонларини ишлаб чиқиш;

- давлат хизматида рахбар кадрлар компетенлигини хақиқий холатини ўрганиш;

- рахбар кадрлар учун компетенциялар моделларини ишлаб чиқиш;

- рахбар кадрларнинг компетенцияларини ривожлантириш учун услубий ёндашувлар ва воситаларни ишлаб чиқиш;

- бошқарув кадрларининг малакасини ошириш технологияларини такомиллаштириш ва х.к. 
Агар масаланинг илк назарий асослари ва ўрганилиш тарихига мурожаат қилинса, бошқарув компетенцияларини тизимли ёндашув асосида ўрганиш А.Н.Аверьянова, В.Г.Афанасьева, И.Д.Андреева, Л.Берталанфи, И.В.Блауберга, М.Б.Бахтина, А.А.Богданова, Е.П.Голубкова, В.Н.Кузьмина, Е.И.Морозова, А. Г. Поршнева, Ю.М.Плотинского, Л.А.Петрушенко, В.Н.Садовского, А.Файоля, Р.А.Фатхутдинова, Ю.И.Черняка, Э.Г.Юдина асарларида маълум маънода ўрганилган. Масалан, И.В.Блауберга асосий компетенциялар ташкилотнинг рақобатбардош устунлигининг потенциал манбаи бўлиб, рахбар кадрларнинг бошқарувга доир ноёб қобилияти, билими ва хулқ-атворини ўзида акс этиради, деб таърифлайди [1.2019. 16(2). 138].

Хусусан, Ўзбекистонда хозирги кунда бу сохада хам тизимли ишлар амалга оширилмокда, албатта. Жумладан, Ўзбекистон Республикаси Президенти хузуридаги Давлат бошқаруви академиясида давлат фуқаролик хизматчиларини қайта тайёрлаш ва малакасини ошириш, шунингдек, янги компетенцияларни ўргатиш бўйича малака ошириш курслари ва семинар-тренинглар олиб борилмоқда. Бироқ рахбар кадрларнинг бошқарув компетенцияларини юксалтириш бўйича курслар глобал пандемия шароитида давлат бошқарувини барча бўғинидаги рахбар кадрлар учун ташкил этилмаяпти. Натижада бошқарув сохасидаги янгиланишлар ва ўзгаришлардан қуйи бўғиндаги рахбар кадрлар бехабар қолмокда.

Тадқиқотчи Э.Г.Юдина асосий компетенциялар - бу менежерларнинг ўзлари тўғридан тўғри идрок эта олмайдиган бошқарувга доир билимлар сифатида қарайди. Шунингдек, бошқарув самарадорлигига таъсир этувчи омил қаторига киради деб таъкидлайди. Юқоридаги фикрларга муносабат сифатида шуни таъкидлаш лозимки, Ўзбекистон Республикаси Президенти хузуридаги Давлат хизматини ривожлантириш агентлиги томонидан давлат органлари ва ташкилотлари ходимлари учун мансаб поғоналаридан кўтарилишда мехнат фаолиятини ахлоқ-ирода сифатлари, иқтидори ва кўникмаларини объектив бахолаш ва малакасини ошириш (ilm.argos.uz) тизими жорий этилмокда. Лекин мазкур тизимдан фойдаланиш имконияти чекланганлиги, фойдаланувчиларни мотивацион рағбатлантириш тизими йўқлиги, давлат хизматчиларини ўз устида ишлаши, бошқарув компетенцияларини ривожлантириб боришга харакат қилишлари юқори даражада эмас.

Давлат фуқаролик хизматчиларининг бошқарув салохиятини юксалтириш назарияси ва амалиёти масаллари Ф.А.Акназарова, Л.П.Арской, Н.М.Бережнова, В.А.Дятлова, М.В.Грачева, Ф. И.Гайнуллинова, А.Гаращенко, Т. И.Демченко, А.П.Егоршина, П.В.Журавлева, Э.М.Короткова, В.В.Корнилова, М.И.Магуры, А.П.Прохорова, В.В.Травина, Ф.Е.Удалова асарларида тадқиқ этилган. Уларда асосан рахбар кадрларнинг касбий ва бошқарув компетенцияларини ривожлантириш, жамиятда содир бўлаётган ўзгаришларга 
мувофиқ тарздаги фаолият мезонлари ва уларни қай тарзда амалга ошириш механизмлари ўрганилган.

Бошқарув сохасида тадқиқот олиб борган М.И.Магуры бошқарув компетенцияларининг рахбар кадрлар профессионаллигини белигилайдиган асосий омил сифатида қарайди. Бошқарув компетенциялари моделларини тахлил қилиб, хар соха учун зарур бўлган бошқарув компетенциялари руйхатини шакллантиради [2. 2010 №5]. Кадрлар компетенциясини ўрганишнинг назарий ва услубий асослари К.Адамса, Р. Бояциса, К. Вудрафа, Р. Дрейкли, В.Дулевича, Л. Зийала, М.Лоузи, Э.М.Короткова, Д. Маккеланда, Б.З. Миль-нера, К.Молони, В.Г.Смирнова, А.Фарнэма, А.Уайта каби олиммлар тадқиқот ишларида ўз ифодасини топган.

Ўзбекистонда хам борада қатор тадқиқотлар амалга оширилмоқда, жумладан Ўзбекистон Бош прокуратураси академияси ходими И.Махмудов томонидан “бошқарув профессионализми” бўйича тадқиқотлар олиб борилиб, бошқарув компетенциялари рахбар профессионализмини ифодалаш бирлиги сифатида қаралади. Мазкур йўналишда ю.ф.д. О.Махкамов томомнидан Ўзбекистон Республикасида кадрлар сиёсати ва давлат фуқаролик хизматининг ўзига хос хусусиятлари тадқиқ этилган [3. Issue -1, №02 (2020) / ISSN 21811415]. Лекин, хозирги глобал пандемия шароитида рахбар кадрларда зарур бўлган бошқарув компетенцияларни: бошқарув фаолиятига доир катта хажмдаги ахборотлар билан ишлаш (Big data), бошқарув фаолиятини рақамлаштириш (digital management), бошқарув фаолиятига доир воқеа, жараён, ходисани бир неча йил олдинга назар ташлаган холда келажакдаги холатини кўздан кечириш, прогнозлаштириш (Foresight), бошқарув фаолиятидаги тизимли муаммоларни тахлил қилиш (Systems analysis), танқидий тахлил қилиш (Systems analysis) ва ноаниқлик шароитида оптимал қарорлар қабул қилиш (Decision-making) кўникма ва малакаларни ўзлаштириш даражаси пастлигича қолмокда.

Тарихчи, сиёсатшунос олим А.Фарнэм компетенцияларни шакллантириш муаммоси сиёсий фан нуқтаи назардан сайлов ва референдумларда, социологик тадқиқотлар жараёнда, яъни халқ билан мулоқот жараёнида, иқтисодиёт нуқтаи назардан бозор муносабатларини амалга ошириш, ишлаб чиқаришни бошқариш жараёнида кўпроқ намоён бўлаётганлигини таъкидлайди. Буни муаллиф қуйидаги жихатлар билан изохлайди:

- бошқарув кадрларини тайёрлаш сифатини ошириш, уларни мураккаб профессионал, ижтимоий ва технологик ечимларга тайёрлаш бўйича кўникмаларини шакллантириш;

- хар хил ёшдаги рахбарлар учун энг мақбул ўқитиш тизимини ишлаб чиқиш [4. 2014. №1 14.10.2021]. Сиёсатшунос олим Д. Эрназаров хозирги глобаллашув жараёнида рахбар кадрларда сиёсий компетенцияларни ютуклиги, ғоявий-мафкуравий курашларда рахбарнинг барқарор фаолиятини таъминлайди деган фикрни илгари суради [5. 
https://tsue.scienceweb.uz/index.php/archive/article/view/256]. Назаримизда мамалакатимизда бўлаётган сайлов жараёнларида рахбарда нафақат бошқарув компетенция балки сиёсий компетенциялар (сиёсий хушёрлик, сиёсий огохлик, сиёсий манфаатларни англаш, сиёсий ташаббус ва хаказо)ни билиши мухим ахамият касб этади.

Ресурс концепциясининг асосчиси Мичиган Университетининг Бизнес Олий мактаби профессори Б. Вернерфелт эди, у 1984 йилда "Фирманинг ресурслар талқини" мақоласини эълон қилган ва у ерда рақобатбардошликнинг хақиқий омиллари айнан фирма ресурслари. Бироқ, илмий ёндашувга илмий ва ишбилармон доираларга бўлган қизиқиш юксалишини 1990 йилда К.Прахалада ва Г.Хамела "Корпорациянинг асосий компетенциялари", бу фирма концепциясининг афзалликларини бизнес бўлинмалари портфели сифатида эмас, балки компетенциялар портфели сифатида тушунтириб беради.

\section{Хорижий олимларнинг “компетенция" га}

доир илмий қарашлари [5. 2011. - 57 c]

\begin{tabular}{|c|c|}
\hline Муаллифлар & \multicolumn{1}{|c|}{ «Компетенция» тушунчасининг мазмуни } \\
\hline Р. Боятцис & $\begin{array}{c}\text { - шахснинг мотивлари, хусусиятлари, кўникмалари, ижтимоий } \\
\text { роли ва билими каби хусусиятлар мажмуи }\end{array}$ \\
\hline $\begin{array}{c}\text { Г.Каннак, } \\
\text { Я.Кибанов }\end{array}$ & $\begin{array}{l}\text { - қисқа вақт ичида кўриб чиқилган, ушбу ташкилот ходимларига } \\
\text { тегишли булган билим, кўникмаларнинг оқилона комбинацияси }\end{array}$ \\
\hline М.Бомензат & \begin{tabular}{l} 
- ходимлар ўртасидаги билим, кўникма ва мулоқот усуллари мажмуи \\
\hline Н.Т.Бунимович
\end{tabular} \\
$\begin{array}{l}\text { - маълум бир сохадаги билим ва тажриба; кимнидир алохида хабардор } \\
\text { қиладиган саволлар доираси }\end{array}$ \\
\hline
\end{tabular}

Хорижий илмий тадқиқотларда бошқарув компетенцияси тушунчаси фанлараро ёндашув асосида ўрганилади. Шунинг учун бошқарув компетенциясини ёритишда масаланинг ижтимоий-сиёсий, психологик, юридик ва менежмент фани қонуниятлари асосида тахлил қилишга зарурият тўғилади. Бу борада кўпгина сиёсатшунос олимлар рахбарнинг бошқарув компетенцияларини бахолашнинг самарадорликнинг мухим кўрсаткичлари (KPI) билан боғлайди, асли бу нотўғри ёндашув, самарадорликнинг мухим куурсаткичлари (KPI) асосида рахбар кадрларнинг асосан мехнат фаолияти бахоланади. Рахбар кадрларнинг бошқарув комптенциялари бу - рахбарнинг бошқарув салохияти, унинг қобилияти ва бошқарув сохасидаги билими ва малкасида ўз ифодасини топади.

Замонавий ахборот жамиятининг билимга асосланган энг мухим қадриятлари бу рахбар кадрларнинг касбий ва бошқарув компетенцияларини ривожлантириш, жамиятда бўладиган ўзгаришларга мос тарзда амалга ошириш тенденцияси кўзатилади. Яъни, Т.Дюран компетенциянинг учта асосий шакли ёки уч ўлчовини таклиф қилади: билим, ноу-хау ва муносабатлар. Унинг фикрича, бошқарув компетенциялари - билим, малака, кўникма, тажриба, масъулият ва ташаббуслардан иборат бўлиши керак, дейди. 
Президентимиз Ш.Мирзиёев “кадрлар салохиятига, уларни халқ билан ишлай олиш қобилиятига алохида эътибор қаратиб, янгича фикрлайдиган, инновацион билим ва тафаккурга эга бўлган, хорижий мамлакатларда таълим олган ёш, иқтидорли кадрларни давлат бошқаруви органларига, корхона ва ташкилотларга, таълим муассасаларига рахбар этиб тайинлаш масаласини давлат сиёсати даражасига кўтарди. Чунки, шиддат билан ўзгариб бораётган замон, давр талаби бошқарув кадрларининг жамият ижтимоий-сиёсий хаётидаги ўрни ва ролига мутлақ бошқача талабларни қўйди. Айниқса, бугунги кунда дунёда юз бераётган иқтисодий-ижтимоий, экологик, диний ва этник муаммолар қаторига коронавирус пандемиясининг кириб келиши нафақат инсонлар соғлиғини сақлаш, шунингдек, уларни пандемия шароитида ишлаши, оиласини боқиш муаммолари хам давлат, жамият олдида яна бир муаммо сифатида кўндаланг кўйилди” [https://uza.uz/uz/].

Европанинг бир қатор давлатларида ва АҚШда бошқарув кадрлар компетентлиги юксалишининг назарий-концептуал асосларини такомиллаштириш бўйича катта назарий ва амалий тажрибалар тўпланган. Хусусан, Д.Девис, Д.Уоррен, Д.Веттен, К.Камерон ва Г.Минсберг каби олимларнинг тадқиқотлари тахлили бизга бир қатор мухим янгиликларни яратишимизга туртки берди. Яъни Европа мамлакатларида бошқарув кадрлари компетенцияларини юксалтиришда қуйидаги тенденцияларга эътибор қаратилган:

-рахбар кадрларнинг ўзгарувчан ролни қайта кўриб чиқиш ва менежерларнинг таълимдаги масъулиятини ошириш;

-рахбар кадрларнинг касбий ва бошқарув компетенцияларни мунтазам бахолаб бориш орқали уларни малака ва кўникмаларини ошириш;

-етакчи кадрлар захирасини яратиш бўйича назарий жихатдан асосланган ва амалда синовдан ўтган тизимларни қиёсий ўрганиб бориш (benchmarking);

- рахбар кадрларни ўқитиш ва малакасини ошириш эмпирик маълумотлар ва тадқиқотларга асосланган;

- ўкув машғулотларида инновацион усуллар, воситалар, замонавий ахборот ва интерактив технологиялар ва имкониятларни тўлиқ ва хар томонлама фойдаланиш;

- семинар тренингларда замонавий рахбарнинг профессионал жихатдан мухим компетенцияларини шакллантиришга эътибор кабилар.

Тадқиқотлар асосида хулоса қилиш мумкинки, хар бир соха учун алохида компетенциялар кластери ва моделини ишлаб чиқиш лозим. мисол учун олий таълим тизимида Олий таълим тизими педагог ва рахбар кадрларни қайта тайёрлаш ва уларнинг битирувсини оширишни ташкил этиш Бош илмий - методик маркази томонидан ўтиладиган хар бир йўналиш тингловчилари учун алохида компетенциялар руйхатини шакллантириш лозим (1-жадвал). 
Бош илмий - методик марказ томонидан «Таълим сифати менежменти» йўналиши бўйича таълим олаётган рахбар кадрларининг компетенциялари шакллантириш бўйича ўкув дастурлари

\begin{tabular}{|c|c|c|}
\hline $\begin{array}{l}\text { Компетен } \\
\text { ция }\end{array}$ & Кутилаётган натижа & $\begin{array}{c}\text { Махсус курслар, модуллар, } \\
\text { интерактив технологиялар } \\
\text { номи }\end{array}$ \\
\hline \multirow{4}{*}{\begin{tabular}{l}
\multicolumn{3}{c}{ Муаммоларни } \\
хал $\quad$ қилиш ва \\
қарор қабул қилиш
\end{tabular}} & \multirow{4}{*}{\begin{tabular}{lrr}
\multicolumn{1}{c}{ Ўз } & ваколатлари \\
доирасида & \multicolumn{2}{c}{ бошқарув } \\
қарорларини қабул & қилиш \\
қобилиятидаги & сифат \\
ўзгаришлари, сифат & учун \\
жавобгарликнинг & намоён \\
бўлиши ва қабул & қилинган \\
қарорларнинг & ўз & вақтида \\
бажарилиши &
\end{tabular}} & \multirow{4}{*}{ 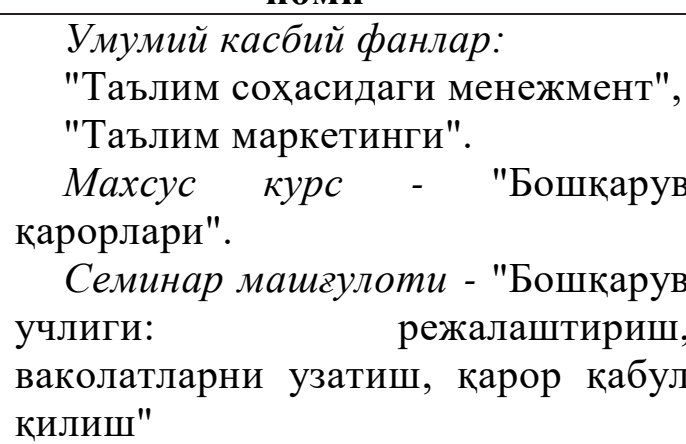 } \\
\hline & & \\
\hline & & \\
\hline & & \\
\hline \multirow[b]{2}{*}{\begin{tabular}{l}
\multicolumn{2}{c}{ Ахборотни } \\
тахлил қилиш, \\
тизимли ёндашув \\
(стратегик \\
фикрлаш)
\end{tabular}} & \multirow[b]{2}{*}{ 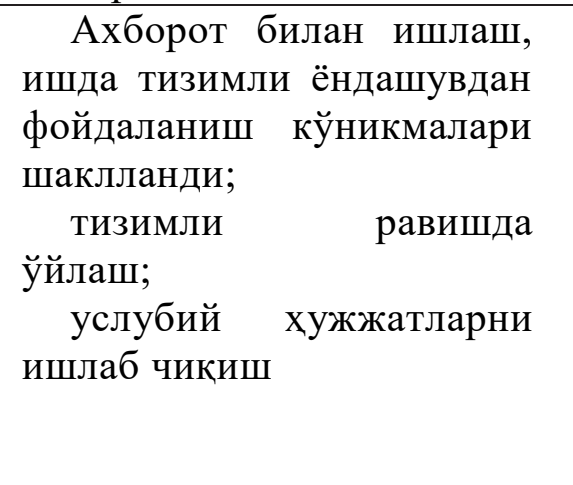 } & \multirow[b]{2}{*}{$\begin{array}{l}\text { Муаммо-тахлил семинарлари: } \\
\text { «Таълим муассасасида иш } \\
\text { юритиш ишларини ташкил этиш», } \\
\text { «Таълим муассасасидаги ахборот } \\
\text { технологиялари», } \\
\text { муассасасида итаълим } \\
\text { бошқариш», иновацияларни } \\
\text { инновацион } \\
\text { ривожлантиришнинг жараёнларини } \\
\text { тендентсиялари ва стратегиялари» }\end{array}$} \\
\hline & & \\
\hline \multirow{2}{*}{$\begin{array}{l}\text { Самарали } \\
\text { алоқа ва жамоа } \\
\text { билан ишлаш }\end{array}$} & \multirow[b]{2}{*}{\begin{tabular}{lr}
\multicolumn{1}{c}{ Умумий } & мақсадларга \\
эришиш, алоқа & ва алоқа \\
тизимини & уррнатиш, \\
барқарор & иш \\
муносабатларини & ўрнатиш \\
учун хамкорлик & мухитини \\
сақлаш қобилиятидаги \\
сифат ўзгаришлари
\end{tabular}} & \multirow[b]{2}{*}{$\begin{array}{l}\text { Умумий касбий фанлар: } \\
\text { "Ишбилармонлик алоқаси", } \\
\text { "ижтимоий психология". } \\
\text { Махсус курс - "Ўзаро таъсир } \\
\text { психологиясининг асослари". } \\
\text { Алоқ̧а буйича тренинг - } \\
\text { "Жамоада ишлаш қобилияти" } \\
\text { Тренинг - "Ўзини самарали } \\
\text { тақдим эта олиш". "Нотиқлик } \\
\text { махорати " }\end{array}$} \\
\hline & & \\
\hline $\begin{array}{l}\quad \text { Ташкилий } \\
\text { корпоратив } \\
\text { маданиятни } \\
\text { бошқариш }\end{array}$ & \begin{tabular}{l}
\multicolumn{1}{c}{ Ишбилармонлик } \\
алоқалари $\quad$ сохасида \\
шаклланган кўникмалар
\end{tabular} & \begin{tabular}{lr}
\multicolumn{1}{c}{ Махсус курслар: } & "Таълим \\
муассасаларини & бошқариш \\
асослари", & «Таълим \\
муассасаларини & бошқариш \\
усуллари», «Таълим муассасасида \\
ходимларни бошқариш». \\
Семинар-тренинг \\
"мулоқотнинг интерактив томони: \\
ўзаро таъсир турлари"
\end{tabular} \\
\hline
\end{tabular}




\begin{tabular}{|c|c|c|}
\hline $\begin{array}{c}\text { Стратегик } \\
\text { режалаштиришга }\end{array}$ & \begin{tabular}{lr}
\multicolumn{1}{c}{ Таълим } & ташкилотини \\
бошқариш & сохасидаги \\
тизимлаштирилган \\
билимлар, \\
бирлик, \\
режалаштириш
\end{tabular} & $\begin{array}{l}\text { Махсус курслар: } \text { "Таълим } \\
\text { тизимларини } \\
\text { "Таълим технологиялари" }\end{array}$ \\
\hline $\begin{array}{c}\text { Натижа учун } \\
\text { жавобгарлик }\end{array}$ & \begin{tabular}{lr}
\multicolumn{1}{c}{ Ижрочилар } & ўртасида \\
асосий & ваколатларни \\
тақсимлаш, & натижага \\
йўналтирилган бошқарув
\end{tabular} & $\begin{array}{l}\text { Семинар-тренинг - "Кадрлар } \\
\text { фаолиятини назорат қилиш ва } \\
\text { бахолаш" }\end{array}$ \\
\hline $\begin{array}{r}\text { Етакчили } \\
\text { к қобилияти }\end{array}$ & \begin{tabular}{l}
\multicolumn{1}{l}{ лидерлик } \\
намоён \\
ташаббулкорли \\
шижоат
\end{tabular} & 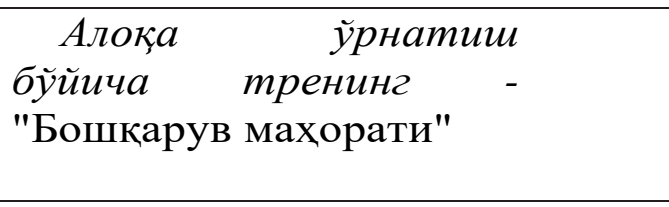 \\
\hline \begin{tabular}{l}
\multicolumn{1}{c}{ Ўз } \\
бахолаш, танқидий \\
фикрлаш
\end{tabular} & $\begin{array}{lr}\text { ўз } & \text { ўзини } \\
\text { ривожлантириш, ўз ўзини } \\
\text { танқидий бахолаш, } \\
\text { ўз устида ишлаш }\end{array}$ & Индивидуал консультациялар \\
\hline $\begin{array}{c}\text { Стрессга } \\
\text { чидамлилик }\end{array}$ & 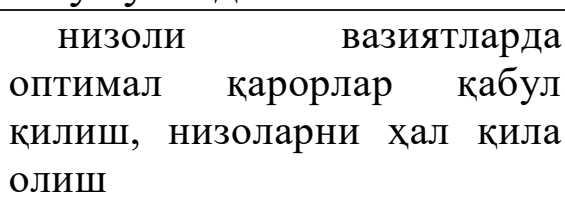 & Тренинг “Эмоционал барқарорлик” \\
\hline
\end{tabular}

Дунё тажрибасига эътибор қаратилса, масалан, давлат хизмати сифатини ошириш мақсадида Малайзия давлати 2002-йилдан компетенцияларга асосланган давлат хизматчиларини тайёрлаш тажрибасига ўтган. Давлат хизматида танлов ва ишга қабул қилиш, малака ошириш ва ривожлантириш, касбни ривожлантириш, ишлашни такомиллаштириш ва тақдирлаш жараёнида компетенциялар бахолаб борилади.

Бугунги замон талаблари ва мамлакатни ривожлантириш шартларига мос равишда давлат бошқаруви тизими самарадорлигини оширишнинг жихатларидан бири давлат бошқаруви кадрларининг профессионаллиги ва компетентлиги хисобланади. Давлат хизматчилари узулуксиз, мунтазам равишда ижодий, шахсий ва касбий билим, салохиятларини ошириб бориши шарт эканлиги мустахкамлаб қўйилган. Бунда давлат хизматчиларининг узлуксиз ривожланиб боришини амалга ошириш учун давлат хизмати тизимига уларнинг касбий ва компетенцияларини ошириш учун мотивациялаштирувчи янгича ёндашувларни жорий этиш назарда тутилган.

Дунё таржрибасида давлат бошқарув органлари фаолиятини ўрганиш шундан далолат берадики, давлат фуқаролик хизматини ривожлантириш бўйича махсус дастур асосида ишлаб чиқилган худудий (махаллий) дастурлар бошқарув кадрлари ва давлат хизматчиларининг касбий салохияти ва компетенцияларини ривожланишини ташкил этиш ва амалга ошириш учун хизмат қилади. Лекин кўпгина МДХ давлатларида бошқарув рахбар кадрлар ва давлат хизматчиларининг касбий салохияти ва компетенциялари ривожланишини бошқариш бўйича айнан бирор бир ваколатли давлат органи ёки ташкилот алохида мазкур 
вазифа билан шуғулланмайди. Ўзбекистонда бу борада дастлабки қадамлар ташланди, яъни бундай фаолият билан Ўзбекистон Республикаси Президенти хузуридаги Давлат хизматини ривожлантириш агентлиги шуғилланиб келмоқда ва ушбу агентлик томонидан талай ташкилий ишлар амалга оширилмоқда.

\section{Хулоса /Выводы /Conclusion:}

Хулоса қилиб айтганда, бошқарув кадрлар компетентлиги юксалишининг назарийконцептуал асосларини такомиллаштиришда давлатнинг рахбар кадрлар тайёрлаш сиёсати ва дунёда кечаётган тенденцияларни хисобга олиш мақсадга мувофиқ. Бир пайтнинг ўзида кадрларнинг профессионал сифатида шахсий ривожланишини бахолаш, салохият ва компетенцияларининг ўсиши мувофиқллаштириш мурраккаб жараён. Шунинг учун мазкур сохада тизимли ислохотларни амалга ошириш керак.

Бизнингча бугунги кунда давлат бошқарувини инновацион ривожлантириш учун рахбар кадрларда куйидаги компетенцияларни юксалтириш зарур:

• самарали мулоқот қила олиши;

• стратегик фикрлаш қобилиятига эга бўлиши;

• ноаниқ вазиятларда харакат қилиш қобилияти мужассам бўлмоғи;

• ижодкорлик махоратининг мавжудлиги;

• ишнинг якуний натижасига эътибор қарата олиши кабилар.

Умуман, бугунги кунда бошқарув кадрларининг компетентлигига кўйилаётган талабларнинг ортиши, улар фаолияти самарадорлигини объектив бахолашнинг зарурияти ва қолаверса касбий ўсишнинг узлуксизлигини таъминлаш бошқарув кадрларининг мехнат самарадорлигини бахолаш бўйича Ўзбекистон Республикаси Президенти хузуридаги Давлат бошқаруви академиясида ташкил этилган “Assessment Centre”-бахолаш марказига бўлган талаб ортмоқда. Бунда давлат хизматчиларининг ваколатлари ва компетенцияларини бахолашда қайси мезонларни танлаш кераклигини аниқлаш, иш самарадорлигининг мақсади ва индикаторларини белгилаш лозим бўлади.

\section{Адабиётлар /Литература /References}

1. Zaslavskaya O.Yu. RUDN Journal of Informatization in Education, 2019, 16(2), 138-14

2. Камалетдинова А. Б. Управленческие компетенции руководителя как фактор создания конкурентного преимущества организации // Электронный журнал «Психологическая наука и образование» www.psyedu.ru / ISSN: 2074-5885 / E-mail: psyedu@mgppu.ru 2010, № 5

3. Жамият ва инновациялар - Общество и инновации - Society and innovations Issue -1, №02 (2020) / ISSN 2181-1415 
4. Пузанова Жанна Васильевна, Корнаухова Юлия Сергеевна Компетентностный подход в образовательной и управленческой практике: модели компетенций // Вестник РУДН. Серия: Социология. 2014. №1. URL: https://cyberleninka.ru/article/n/kompetentnostnyypodhod-v-obrazovatelnoy-i-upravlencheskoy-praktike-modeli-kompetentsiy (дата обращения: 14.10.2021).

5. https://tsue.scienceweb.uz/index.php/archive/article/view/256

6. Ксенофонтова Х.З. Компетенции управленческого персонала: теория и методология развития: Монография. - М.: Креативная экономика, 2011. - 54 с. 